\title{
The Mechanisms of Autoimmune Response : Insights into an Enigmatic Repertoire
}

\author{
Wihaskoro Sosroseno ${ }^{1,3}$, Endang Herminajeng ${ }^{2}$
}

\begin{abstract}
Abstrak
Makalah ini mendiskusikan penelitian-penelitian tentang mekanisme respon autoimunitas yang menjebabkan terjadinja penjakit autoimun. Kegagalan toleransi sel B dan $T$ autoreakrif, kurang berfungsinya sel $T$ supresor, kerusakan mekanisme apoptosis, peningkattan ekspresi superantigen, efek samping sitokin, dan kemungkinan infeksi mikrobial dianggap sebagai mekanisme jang bertanggung jawab terhadap terjadinja respon autoimunitas. Namun, terlihat balwwa sulit menerapkan satu mekanisme autoimunitas untuk menerangkan terjadinja satu macam penjakit tersebut; dengan kata lain, satu penyakit autoimun mungkin akibat dari kombinasi mekanisme tersebut. Perlu pula diteliti lebih lanjut untuk menggunakan hasil penelitian yang memakai model binatang percobaan pada manusia.
\end{abstract}

\begin{abstract}
Several possible mechanisms of autoimmune response leading to the development of autoimmune diseases are discussed briefly' herein. Failure of both $B$ and $T$ cell tolerance, lack of suppressor $T$ cell funcrions, an apoptosis defect, increased expression of superantigens, adverse effects of cytokines and possible microbial infections have all been proposed as the mechanisms of autoimmune response. Yet, none of the proposed mechanisms seems to explain satisfactorily' and exclusively the development of a single autoimmune disease, suggesting that the diseases may involve complex mechanisms rather than due to a single parlway). Whether findings based upon the animal models can be extrapolated in humans remains also to be investigated further, since it would provide a direction for future bimodal therapy.
\end{abstract}

Keywords : Immunoregulation, autoimmunity, autoimmune diseases

The induction of the immune system following an antigen recognition involves highly complex interaction of all immunocompetent cells and molecules. It is in this respect that the ability to recognize both selfand non self antigens is a key feature of the immune system. Thus, failure to suppress the immune response against self antigens would result in the inducttion of autoimmune response; ${ }^{1}$ however, the exact mechanism by which the autoimmune response occurs remains questionable. Distinct mechanisms such as failure of deletion of autoreactive $T$ and $B$ cells have been reported. Yet, whether these proposed mechanisms can explain the immunopathogenesis of all known autoimmune diseases is unclear, since each of these diseases is characteristically distinct in terms of the autoan-

Department Dental Public Health', Department of Oral Surgery ${ }^{2}$, Faculty of Dentistry ${ }^{1,2}$, IUC-Biotechnology and Laboratory of Life Science, ${ }^{3}$ Gadjah Mada University; Yogyakarta, Indonesia tigen-activated effector cells and/or molecules. The aim of this paper is to discuss several proposed mechanisms of the autoinmmune response and its association with the development of certain autoimmune diseases.

\section{Failure of self-T cell tolerance}

Both intra and extrathymic development of $\mathrm{T}$ cells which result in the ability of the cells to discriminate between self- and non self antigens are perhaps one of the central questions among immunologist. The precise mechanism by which these phenomena occur is still far from clear; however, two debatable pathways, i.e., clonal deletion and clonal anergy, have been put forward to explain the $T$ cell negative selection during its ontogeny in both intra thymic (central) and extrathymic (peripheral) environment. ${ }^{2}$

Clonal delettion or elimination of self-reactive $\mathrm{T}$ cells is considered as the main mechanism of the $\mathrm{T}$ cell 
negative selection intrathymically, based on the fact that lack of self-reactive $T$ cell clones bearing VB ( $T$ cell receptor $B$ locus) occurs. ${ }^{3}$ In this respectt, the transitional development of double negative to double positive thymocytes requires the presence of $\mathrm{T}$ cell receptor (TcR) B locus, suggesting that lack of this locus would result in failure of deletion of self-reactive $\mathrm{T}$ cells. The mechanisms by which clonal deletion occurs remains obscure. It seems that major histocompatibility (MHC) molecule-bearing thymic epithelial and mesenchyme cells determine such selection. Both cells are required to develop $\mathrm{TCR}^{-} \mathrm{CD} 4^{-} \mathrm{CD} 8^{-}$cells to $\mathrm{TCR}^{+} \mathrm{CD} 4^{+} \mathrm{CD} 8^{+}$cells in the thymus, ${ }^{5}$ whereas TCRbearing thymocytes which recognize self antigenpresenting thymic dendritic cells would be negleted. ${ }^{6}$ How autoreactive $\mathrm{T}$ cells evade the clonal deletionmediated negative selection remains to be elucidated; it seems that, increased expression of endogenous superantigens such as Mls in mice would result selectively in deletion of $V B$ locus-bearing $T$ cells (see also below). ${ }^{7}$

However many investigators believe that it is difficult to reconcile the clonal deletion as a sole mechanism in the $\mathrm{T}$ cell development. In animal models of systemic lupus erythematosus (SLE), no clonal deletion occurs and normal TCR Vß expression can be detected. ${ }^{8}$ It has also been argued a VB usage as the mere explanation of autoimmune response due to the fact that in autoimmune diseases such as multiple sclerosis (MS), sharing TCR VB-CDR3 region rather than $V \beta$ alone is commonly seen. ${ }^{9}$ Clonal anergy rather than clonal deletion can also be seen in a study showing that peptide-hyperactivated human $\mathrm{T}$ cell clones failed to proliferate, following restimulation with optimal doses of peptides. ${ }^{10}$ Using an in vitro system, it appears that following recognition of self antigens, $T$ cell anergy is mediated by lack of IL-2 production for self growth, perhaps due to antigen presentation function of nonprofessional antigen presenting cells (APC). ${ }^{11,12} \mathrm{It}$ has, in this respect, been shown that in transgenic mice expressing MHC class II on pancreatic beta cells, T cells recognizing transgenic proteins presented by islet beta cells were functionally tolerant, suggesting that $\mathrm{T}$ cell anergy caused by autoantigen recognition occurs. ${ }^{13}$ Thus, clonal anergy can be regarded as the mechanism of autoreactive $T$ cell tolerance in the peripheral sites. Whether failure of peripheral $\mathrm{T}$ cell tolerance generating the autoimmune response is due to the function of "proper" type of APC is therefore worthy to determine. Using BXSB mice $\left(\mathrm{H}-2^{\mathrm{b}}\right)$ which spontaneously develop SLE, insertion of $\mathrm{E}^{\mathrm{d}}$ gene to fertilized eggs of these mice prevented mice from hypergammaglobulin, autoantibody production and autoimmune glomerulonephritis. ${ }^{14}$ In this study, I-E $\alpha$ chain-derived peptides were presented by I-A molecules of $B$ cells, implying that these peptides competed with autoantigens on I-A molecules of B cells. One may assume therefore that $B$ cells indeed present autoantigens to autoreactive $\mathrm{T}$ cells, but this event is preventable by other unrelated peptides. It should however be noted that clonal deletion may, to some extent, occur in the peripheral or postthymic sites, due to an extremely compelling response to immunogens. ${ }^{11}$ Not surprisingly, peripheral self-T cell tolerance involves a multistep event which may in turn maintain both physical and functional depletion of autoreactive T cells. ${ }^{15}$

The evidence implicating the role of T cells, particularly CD4 cells, in the development of autoimmune diseases is overwhelming. The question remains however whether activated autoreactive CD4 cells are resulted from the failure of central and/or peripheral $\mathrm{T}$ cell tolerance. In myastenia gravis (MSG) muscle acetylcholine receptor (AChR)-specific CD4 cells helped $B$ cells to produce autoantibodies if $\mathrm{CD} 8$ cells were removed, ${ }^{16}$ suggesting that this autoimmune response is due to failure of CD8 cells to downregulate autoantigen-activated CD4 cells rather than failure of central T cell tolerance per se (see also below). In fact, suppressed AChR-specific antibody production in the MSG patient- derived B and CD 4 cell coculture system was mediated by suppressor macrophages, but not CD 8 cells, ${ }^{17}$ supporting the above contention. Similarly, enhanced expression of myelin basic protein (MBP) in MS may be presented by local APC such as microgial cells to naive CD4 cells which are in turn activated to become autoantigen-reactive CD4 cells, ${ }^{18}$ suggesting that peripheral $\mathrm{T}$ cell tolerance fails to occur. Of interest, the occurrence of this diseases is strongly associated with TCR Vß-CDR3 expression. 9 Thus, whether this disease is due to failure of central and/or peripheral tolerance remains to be elucidated. Failure to delete clonaly autoreactive $T$ cells can also be seen in the development of autoimmune gastritis in which immunisation of gastric proton pump-derived $\alpha$ and $\beta$ subunit in the presence of adjuvant induced the organ specific autoimmune disease in an animal model. ${ }^{19}$ Based upon these findings, it seems plausible, therefore, that failure of one of the clonal selection theories would only mediate specifically certain but not all types of autoimmune diseases.

Should both clonal negative $\mathrm{T}$ cell selection theories not be sufficient to delete the development of autoreactive $T$ cells, it needs other explanation to determine the persisted autoimmune response in this cell repertoire. 
One possible mechanism of $\mathrm{T}$ cell tolerance is the "ignorance" of $\mathrm{T}$ cells to self antigens. ${ }^{20}$ In this proposed mechanism, two possible concepts, i.e., affinity binding and accessibility, have been put forward. Clonal selection-evading autoreactive $\mathrm{T}$ cells would normally have low affinity in binding with self antigen-bearing APC. Under certain not yet defined circumstances, increased expression of self antigens could occur and, in turn, attract the T cell-APC binding, leading to autoreactive $\mathrm{T}$ cell activation. This concept comes from elegant studies using three sets of transgenic mice, i.e., RIP-K ${ }^{b}$ mice expressing class I $\mathrm{MHC}$ gene $\mathrm{H}-2 \mathrm{~K}^{\mathrm{b}}$ on islet $\mathrm{B}$ cells, Des-TcR mice expressing $\mathrm{TcR}$ anti- $\mathrm{K}^{\mathrm{b}}$ antibodies and RIP-IL- 2 mice expressing RIP-controlled IL-2 gene. ${ }^{21,22}$ No cell infiltration on pancreatic islets could be seen in RIP-K ${ }^{b}$ $X$ Des- $T c R F_{\perp}$ mice, even though anti- $K^{b} T$ cells were numerous. However, if RIP-K ${ }^{b}$ X Des-TcR $F_{1}$ mice were matched with RIP-IL-2 mice, $B$ cell destruction and diabetes could occur in these triply transgenic mice. These results suggest therefore that high levels of IL-2 may enhance the expression of self-antigens which are then capable of stimulating $T$ cell-mediated autoimmune response. The accessibility-related concept is presumably associated with the structure of antigens. Sequestered self antigen is commonly unaccessible to be recognized by $\mathrm{T}$ cells; however, some molecules may appropriately be presented and recognized by $T$ cells which are then being activated. The second concept can be seen from a study showing that whole murine cytochrome $\mathrm{c}$ failed to induce $\mathrm{T}$ cell activation, but peptide 81-104 derived from these proteins elicited $\mathrm{T}$ cell response, suggesting that self antigen-derived certain peptides which are commonly unexposed may induce autoimmune response of $\mathrm{T}$ cell repertoire. ${ }^{23}$ However, the extrapolation of these studies in the development of autoimmune diseases needs to be elucidated.

\section{Failure of self-B cell tolerance}

Using transgenic mice, it appears that the fate of autoreactive $\mathrm{B}$ cells closely resemble that of T cells. In transgenic mice expressing hen egg lysosome, immunisation of the lysosome has resulted in suppressed specific antibody production without physical loss of $B$ cells, suggesting that autoreactive B cells undergo clonal anergy. ${ }^{24}$ In sharp contrast, transgenic mice carrying genes encoding anti-MHC antibodies become tolerant to appropriate self antigens by deleting MHCspecific B cells, suggesting that clonal deletion occurs. ${ }^{25}$ Clonally deleted self- reactive B cells have also been shown by using transgenic mice carrying genes encoding anti-CD8.2 immunoglobulin mu chain. ${ }^{26}$
Activated autoreactive B cells which produce autoantibodies are believed to play a crucial role in the development of certain autoimmune diseases. ${ }^{27}$ However, the mechanism by which autoreactive $B$ cells can be activated to induce the autoimmune response is not fully understood. In lysosome transgenic mice, selfreactive $B$ cells were inactivated. ${ }^{28}$ In this study, if continuous autoantigenic stimulation was removed, these putative cells would then be responsive to LPS or CD4 cells, suggesting that self-reactive B cells may be activated polyclonally. One possibility is that polyclonal B cell activation may be enhanced by high levels of IL- 6 as seen in patients with SLE. ${ }^{29,30}$

Studies using the lysosome transgenic mice have also provided a line of evidence that functionally silent autoreactive $\mathrm{B}$ cells can be activated following an intimate T-B cell interaction. Thus, autoantigen-activated CD4 cells help naive or autoreactive $B$ cells to produce specific autoantibodies. A support can be drawn from graft-versus-host- and chemical-induced experimental systemic autoimmune diseases. ${ }^{31}$ In this study, IL-4-producing CD4 cells were activated by alloantigens and chemicals such as mercury and they in turn provided signals for $\mathrm{B}$ cell activation to produce autoantibodies such as anti-DNA antibodies. Likewise, in vivo depletion of CD4 cells with monoclonal anti-CD4 cell antibodies has resulted in inhibition of autoantibody production in an animal model of SLE and $\mathrm{MS}^{32}$

During the generation of antibody diversity, somatic hypermutation of rearranged immunoglobulin Vregion genes is required to produce high affinity antibodies. ${ }^{33}$ It is in this respect that anti-DNA autoantibodies from autoimmune mice show extensive hypermutation of $V$-region genes and appear to have high affinity to self-antigens. ${ }^{34}$ Indeed, $\mathrm{Ig}-\mathrm{V}$ gene usage is seen more frequently in SLE patients than in normal subjects. ${ }^{35}$ Thus, it is possible that following secondary autoantigen recognition, self-reactive $B$ cells which normally produce low affinity antibodies and do not respond to self-antigens undergo somatic hypermutation. Despite the fact that this contention remains speculative, this pathway may reflect that these putative $B$ cells evade the clonal anergy.

\section{The role of suppressor $\mathrm{T}$ (Ts) cells}

The existence of suppressor T (Ts) cells as a negative regulator of both cell- and humoral-mediated immune response is well known. Recent findings on the cytokine profile of this cell population in which Ts 
cells can be divided into two types, i.e., IFN- $\gamma$ - producing Ts cells type 1 and IL-4-producing Ts cells type 2, have sharpened the role of this $\mathrm{T}$ cell subpopulation in the immune response. ${ }^{36,37}$

The exact role of Ts cells in the development of autoimmune response is still debatable and appears to depend upon the nature of specific autoimmune diseases. In the case of experimental autoimmune interstitial nephritis, tubular antigen-specific $\mathrm{CD} 8$ cells are the effector cells capable of developing cell-mediated immune response and damaging renal tubular basement membrane. ${ }^{38}$ Surprisingly, the initial activation of these cells are inhibited by $\mathrm{CD}^{+}$suppressor cells (Ts1) which in turn induce transforming growth factor (TGF)-B1-producing $\mathrm{CD} 8^{+}$cells (Ts2) acting as suppressor cells for the tubular-specific effector cell activity. ${ }^{39,40}$ On the otherhand, observations in diseases such as uveitis, MS and SLE suggested that Ts (CD8) cells fail to suppress the induction of autoreactive CD4 effector cells. ${ }^{41}$ In experimental allergic encephalomyelitis (EAE), an animal model of human MS, lack of functionally active TS cells occurs in genetically susceptible animals, suggesting that Ts cells are protective in EAE, perhaps via the action of Ts cellderived TGF- $\beta^{42,43}$ Thus, adoptive transfer of Ts cells isolated from spontaneously recovery EAE inhibited the induction of EAE in the recipients and proliferation of myelin basic protein (MBP) specific $T$ cell lines in vitro. ${ }^{44}$ Likewise, in vivo depletion of Ts (CD8) cells using a respective monoclonal antibody increased the susceptibility to develop mercury chloride-induced autoimmune response in Brown Norway rats. ${ }^{45}$ Functionally impaired Ts cells in these diseases have also been shown by using oral administration of the respective antigens. This route of antigen administration has led to induce specific Ts cells and reduce the course of diseases such as MS, uveitis and rheumatoid arthritis (RA) in both animal models and human studies. ${ }^{46,47}$ Moreover, depletion of Ts (CD8) cells in vivo by injecting anti-CD8 cell monoclonal antibodies did not prevent the induction of experimental autoimmune uveitis (EAU) in Lewis rats, ${ }^{48}$ and accumulated evidences seem to suggest that Ts (CD8) cells function to suppress $\mathrm{S}$-antigen or interphotoreceptor retinoidbinding protein-specific T cell activity in EAU. ${ }^{49}$

Whilst the above discussion reveals that Ts suppressor cells of both CD4 and CD8 cell phenotypes play a crucial role in suppressing autoantigen-specific $\mathrm{T}$ cell functions, not all models follow this pathway. In MSG, suppressed AChR-specific CD4 cell activation was not associated with Ts (CD8) cell functions, rather it was mediated by suppressor macrophages. ${ }^{17}$ As yet, no clear explanation can be forwarded for this discrepancy. Presumably, the precise time at which CD8 cells function in this disorder as seen in the murine nephritis model is important in determining the role of these cells in vivo. ${ }^{38-40}$

\section{The role of apoptosis (programmed cell death)}

Apoptosis is a phenomenon of the cell death driven physiologically by activated genes such as Fas and shown by condensed cellular cytoplasm and chromatin. ${ }^{50}$ In the immune system, along with the possible mechanisms as discussed above, clonal deletion of both thymocytes and peripheral autoreactive $T$ cells has been demonstrated due to apoptosis. ${ }^{51}$ Yet, it has been argued that the negative selection of thymocytes may occur due to simply terminal differentiation rather than due to apoptosis. ${ }^{7}$ Despite the controversial evidences, apoptosis-induced $\mathrm{B}$ and $\mathrm{T}$ cell tolerance are relevant to the possibility that autoimmune response is partly due to impaired apoptosis.

Since lpr gene is mapped to the same area of chromosome of Fas gene, it has been postulated therefore that spontaneously developed SLE in murine homozygous for $l p r$ is due to defect of Fas gene. ${ }^{52}$ Indeed, it is now recognized that different strains of mice which develop spontaneous autoimmune disorders have mutation in apoptosis-associated genes. For example, in $M R L-l p r / l p r$ mice, defect of Fas gene expression is due to insertion of a retrotransposon into the second intron of the Fas gene. ${ }^{53,54}$ These phenomena may explain lymphoproliferative disorder, loss of $\mathrm{T}$ cell tolerance and $\mathrm{B}$ cell defect occurring in these mice. The apoptosis defect seems also to occur in SLE patients as seen in a study carried out by Cheng and colleaques. ${ }^{55}$ In this study, increase of soluble form of the Fas molecules was accompanied by reduced apoptosis, suggesting that increased expression of these soluble molecules would result in altered clonal negative selection of autoreactive cells which would in turn lead to initiate the induction of autoimmune disease.

The apoptosis defect may not only be associated with the failure of $F$ as gene expression, but also with increased expression of Bcl-2 gene. Bcl-2 (B-cell lymphoma/leukemia-2) gene is frequently translocated in immunoglobulin locus of follicular B-cell lymphoma and its expression is related with cell survival; hence, this gene functions as an inhibitor for apoptosis. ${ }^{56,57}$ In this respect, Strasser and colleaques have shown that enhanced expression of $\mathrm{Bcl}-2$ resulted in sustained 
survival of B cells and aged transgenic mice carrying this gene developed autoimmune disease. ${ }^{58}$ In SLE patients, circulating CD4 and CD8 cells, but not B cells, expressed high level of Bcl-2 protein, whereas increased expression of Bcl-2 mRNA in mononuclear cells could be seen, suggesting that dysregulation of apoptosis in lymphocyte population may occur in these patients. ${ }^{59}$ These findings demonstrate that altered Bcl-2 expression may result in the failure of autoreactive $\mathrm{B}$ and/or $\mathrm{T}$ cell deletion which in turn accelerates the autoimmune response. The precise mechanism by which altered $\mathrm{Bcl}-2$ gene expression occurs in autoimmune disease is however uncertain, since several evidences revealed that $\mathrm{Bcl}-2$ gene failed to induce the survival of self-reactive B cells. ${ }^{57}$ Of interest, insertion of retroviral gene into the myeloid leukemia cell line (HL-60 cell line) was able to over-express this gene. ${ }^{60}$ By analogous, one may assume that viral infections which are suspected to associate with certain autoimmune diseases such as type I diabetes mellitus ${ }^{61}$ may increase the expression of this gene, leading to induce longer life-span of both autoreactive $B$ and $T$ cells. The contention remains speculative and needs to be investigated further.

\section{The role of superantigens}

Superantigens such as Staphylococcus enterotoxins B (SEB), ${ }^{62}$ group A streptococcal antigens ${ }^{63}$ and mouse mammary tumor viruses (MMTV) ${ }^{64}$ have been shown to activate $\mathrm{T}$ cells specifically and more efficiently than in the classical MHC-peptide interaction. Unlike the classical $\mathrm{T}$ cell recognition in which antigens must be processed and presented by APC in small peptides, superantigens can be presented as entire molecules. In fact, crosslink between $\mathrm{MHC}$ and TcR molecule, especially at VB region, can be mediated by superantigen at the lateral site, whereas classical antigens lie in the relatively centre site of the interaction (see Figure 1). ${ }^{65}$ Food poisoning and toxic shock syndrome are among the diseases associated with superantigens.

The role of superantigens in the development of autoimmunity has been a focus of investigations, but

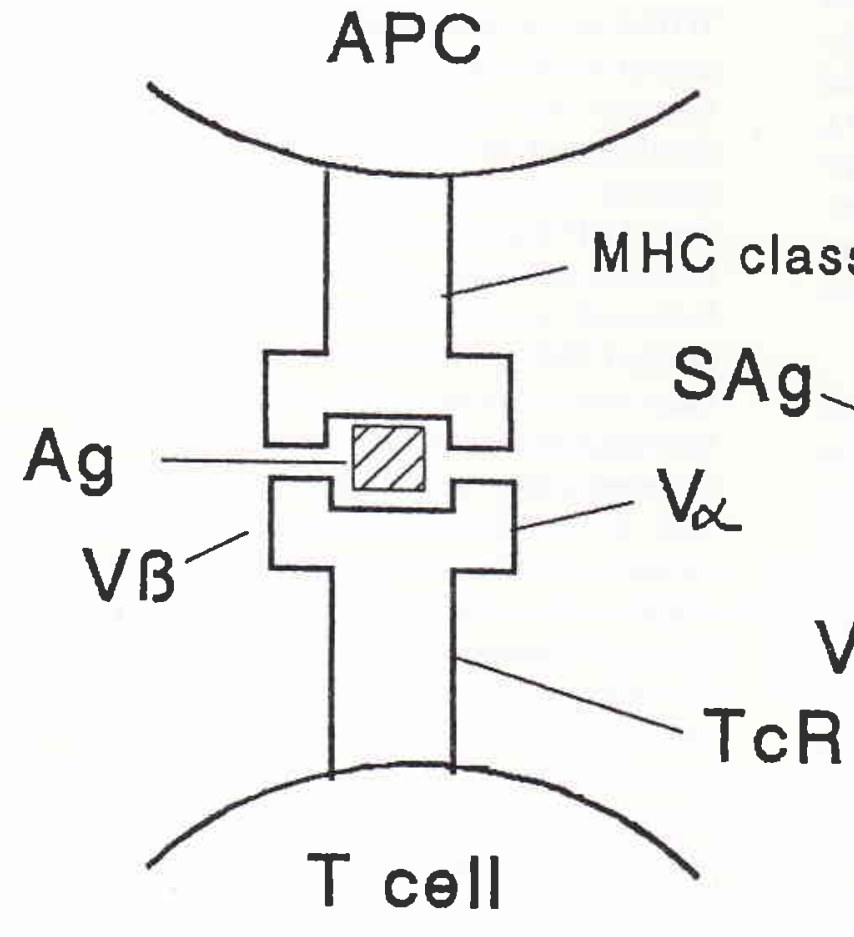

A
APC

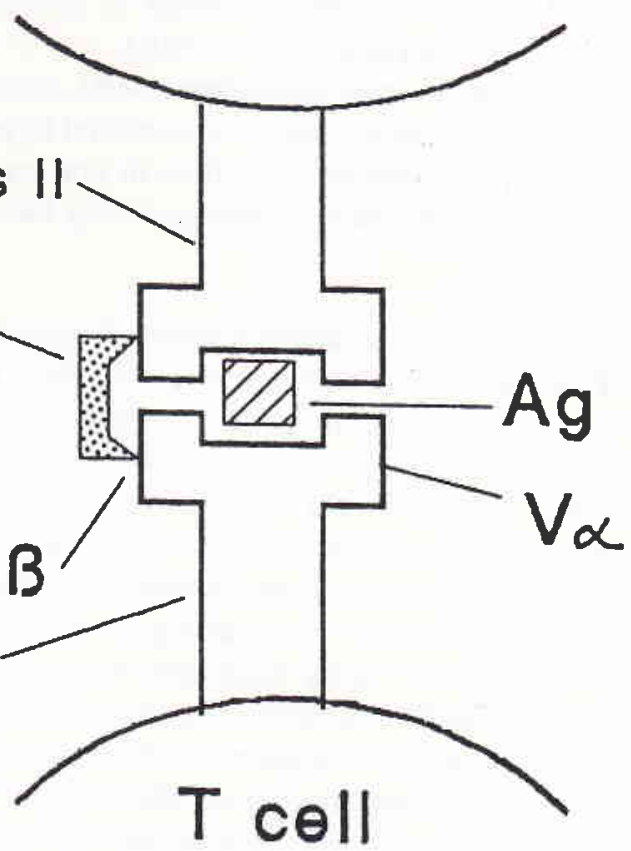

B

Figure 1. Antigen and superantigen recognition involving $M H C$ and TCR molecule interaction. CD4 and CD8 molecule amplify the interaction, but are not shown herein (A). Processed antigen peptides $(A g)$ are presented by antigen presenting cells in association with MHC class II or class I molecule to T cells bearing T cell receptors (TCR). (B) Superantigens (SAg) crosslink the VB region of
$T C R$ and MHC class II molecule. 
not yet precisely defined. Since such antigens can induce polyclonally $\mathrm{B}$ cell and specifically $\mathrm{T}$ cell activation, one or two cells in the autoreactive cell repertoire may be activated; with other words, superantigens may break the existence of self-tolerance. Rheumatoid arthritis (RA) and MS are among autoimmune diseases in which superantigens may involve. ${ }^{65}$ In the case of MS, retroviruses have been believed to play a role, suggesting microbial infections may be involved. ${ }^{66}$ Two separate lines of evidences may support the role of superantigens in MS. First, T cells infiltration in the central nervous system in EAE were predominated by Th1 cells. ${ }^{67}$ Secondly, superantigens induce preferentially Th 1 cell activation, at least, via the production of TGF-B. ${ }^{68-70}$ Furthermore, increased number of VB17positive $T$ cells in patients with RA, compared to those in the controls could be observed, suggesting that the development of RA may be associated with superantigen infections. ${ }^{71}$ One should however be cautious in extrapolating this study into a general conclusion, since this study did not show whether increased number of this cell population was accompanied by increased expression of superantigen-derived peptides. A direct evidence showing a superantigen-RA relationship comes obviously from animal models. Injection of SEB resulted in high number of synovial cells in VB8 TcR transgenic mice (MRL $-+/+$ ), compared to those in non transgenic MRL-lpr/lpr mice. ${ }^{72}$ In this study, higher degree of synovial hyperplasia was seen in transgenic mice than in non transgenic mice, suggesting that superantigens may induce chronic arthritis.

It seems plausible that superantigen-induced autoreactive $B$ or $T$ cell activation still needs to encounter the respective autoantigens, in order to develop the specific autoimmune response. ${ }^{65}$ In EAE, superantigen-activated $T$ cells would then be reactivated by MBP presented by microglia cells or astrocytes in the brain, ${ }^{16,73}$ suggesting that the secondary autoantigen challenge is required in superantigen-mediated autoimmune response. Using SEB and toxic shock syndrome toxin (TSST)-1, a superantigen produced by Staphylococcus aureus B, it appears that both superantigens bound to the same region of HLA-DR $1{ }^{74,75}$ These studies also revealed that whilst the binding of these superantigens onto the region of DR 1 molecules was dependent upon the classical antigen peptides, they did not block each other completely, suggesting that the classical antigen peptides direct the superantigen binding and that superantigen-induced $T$ cell activation may still be dependent upon the antigen peptides. These findings imply therefore that the secondary challenge by the respective autoantigens is indeed a prerequisite in determining the role of superantigen-associated autoimmune response; with other words, superantigens may be a predisposition in the induction of autoimmune response. Care should however be taken in extrapolating the data based upon VB expression into the possible role of superantigens in these diseases, since the idea of VB-associated autoimmune diseases still needs to be investigated further. ${ }^{9}$ Indeed, $V \alpha$ expression would also be important in determining tight MHC-TcR-superantigen interaction if the MHC-superantigen crosslink is weak. ${ }^{76}$

\section{The role of cytokines}

During antigen-driven immune response, signals provided by cytokines to activate the immunocompetent cells and molecules are prerequisite. Indeed, cytokines are not only important in protection, but also in maintaining autoreactive $B$ and $T$ cell activation and inducing tissue destruction. ${ }^{77}$ Cytokines such as IL-6 may in fact induce secretion of proteinases such as granzymes which in turn damage target cells and release autoantigens as seen in multiple sclerosis. ${ }^{78}$ TGF- $\beta$ can be protective in this disease as seen in an animal model, perhaps by inhibiting IL-1 production, whereas this cytokine has been implicated in the development of RA, by recruiting leukocytes in the synovial tissues. ${ }^{79}$ However, injection of monoclonal anti- TGF- $B$ antibodies reduced the severity of streptococcal cell wall- induced arthritis in a rat model. ${ }^{80}$ Increased levels of IL-4, IFN- $\gamma$ and IL- 1 , but suppressed TNF- $\alpha$ in SLE have also been reported. ${ }^{30}$ The exact role of these impaired cytokine levels in SLE is still obscure; likely, high levels of IL-5 may play a role in determining the activation of $\mathrm{CD5}^{+} \mathrm{B}$ cells which may in turn produce autoantibodies in SLE. ${ }^{81}$ This cytokine profile of SLE patients is in fact parallel with studies using the animal models. For example, continuous injection of anti-IL-10 antibodies in NZB/W F1 mice resulted in reducing the severity of spontaneously developed lupus-like autoimmunity and increased serum levels of TNF- $\alpha{ }^{82}$ These findings suggest therefore that TNF- $\alpha$ is protective in SLE. In insulin-dependent diabetes mellitus, monocytederived IL-1 may be destructive to islet beta cells which would then release their autoantigens. ${ }^{61}$ Increased levels of IFN- $\gamma$ in Behçet syndrome have been suggested to upregulate NK cell activities.$^{83}$ Likewise, the induction of cellular immune response in blister formation as well as increased autoantigen gene expression in cultured keratinocytes has been associated with excessive production of IFN- $\gamma$ in bullous pemphigoid. ${ }^{84,85}$ 
The regulatory roles of cytokines such as IL- 1 and TNF- $\alpha$ in the development of RA are of interest. High levels of IL-1 in the synovial fluid suggest that this cytokine plays a crucial role in this disease. In response to IL-1, synovial fibroblasts of RA patients produced MCAF (monocyte chemotactic and activating factor) and $\mathrm{PGE}_{2}$, suggesting that IL-1 may involve in macrophage accumulation and both pain and edema associated with rheumatoid synovitis. ${ }^{86,87}$ If treatment of RA patients with methotrexate (MTX) has resulted in reduced IL-1 levels of synovial fluid, ${ }^{88}$ this treatment regiment might decrease the severity of RA. Furthermore, one of the TNF- $\alpha$ activities in RA may be associated with hyaluronan (HA), a marker of synovial proliferation, since increased HA production is significantly correlated with increased levels of this cytokine. ${ }^{89}$ The most important role of this cytokine in RA is perhaps related with its ability to induce IL-1 production, but suppress GM-CSF production, suggesting that downregulated TNF- $\alpha$ production would be beneficial. ${ }^{77}$ Indeed, injection of anti-TNF- $\alpha$ antibodies before or during the arthritis process significantly suppressed the severity of collagen-induced arthritis in mice. ${ }^{90}$

\section{The role of microorganisms}

Certain microbial antigen-derived peptides which are presented by MHC class II molecules share homology with self peptides derived from HLA-DR $\alpha$, suggesting that microbial peptide-activated $\mathrm{T}$ cells may be able to recognize self-antigen presented by MHC class II and initiate autoimmune response. This phenomenon is termed as the antigenic mimicry. For example, in ankylosing spondylitis, Klebsiella organisms can modify HLA-B27 negative to -B27 positive like persons, suggesting that infection due to these organisms may enhance the individual susceptibility to develop this autoimmune disease. ${ }^{91}$ Other microenvironmental antigens such as a $75 \mathrm{kD}$ heat shock protein (Hsp70) of Trypanosoma brucei, RfbA protein of Salmonella typhimurium, and periplasmic protein of Treponema pallidum have shown to have amino acid homology at certain position with HLA-DR $\alpha$ sequence, implying that these antigens may trigger the development of certain autoimmune diseases. ${ }^{92}$

The antigenic mimicry hypothesis seems to rely on the existence of HLA-DR expression, but it may not always be the case for the development of certain autoimmune diseases such as RA. Some of the population carrying HLA-DR1 or DR4B do not develop this disease, suggesting that a definite conclusion to show a correlation of HLA-DR expression and RA is scanty. ${ }^{93}$ In fact, mycobacterium-induced infection shows similar features seen in this autoimmune disease. Thus, elevated levels of rheumatoid factors, agalactosyl immunoglobulin $G$, and antibodies to mycobacterial Hsp65 can be detected in this infection, suggesting that rheumatoid arthritis is a slow bacterial infection. ${ }^{94,95}$ The mechanism(s) underlying this phenomenon is unknown and needs to be elucidated further. It has been postulated that microbial antigens originated from extra-articular sites such as the gut or lung would be processed and presented by synovial APC to activate $T$ cells which in turn trigger synovial macrophages to release tissue-damaging mediators. ${ }^{95}$ Perhaps, the slow bacterial infection may also be a good candidate in explaining the pathogenesis of Behçet's syndrome, since high levels of $\mathrm{IgA}$ and $\mathrm{IgG}$ antibodies from patients with this disease react with 65 to $70 \mathrm{kD}$ heat shock protein (Hsp) derived from Streptococcus sanguis. ${ }^{96}$ It is unclear how these microbial antigens induce this disease. Yet, it may be that the pathogenesis of Streptococcal HSP65-induced Behçet syndrome is similar to that of Mycobacterial-induced RA, since $S$. sanguis-derived Hsp65 shares homology to Mycobacterial Hsp65 and high levels of antibodies specific to both microbial antigens can be observed in both autoimmune disorders. ${ }^{96}$ Of interest, Hsp60-derived amino acids $336-351$ and $136-150$ which are $T$ epitops of this syndrome were able to induce uveitis in Lewis rats, ${ }^{97}$ suggesting that mycobacterial infections may induce both autoimmune diseases.

\section{CONCLUSION}

Distinct mechanisms implicated in the induction of autoimmune response have been proposed; however, it seems that none of them is able to explain satisfactorily and exclusively the occurrence of a single autoimmune disease. It is safely to say that the induction of autoimmune response is a complex interaction involving many possible pathways. Of important, other effector molecules such as complements, idiotypic antibodies and adhesion molecules may also play a crucial role in the induction of these diseases. Fresh ideas with substantial evidences, at the present time, are desperately needed to delineate this phenomenon. A slow bacterial infection as a possible etiology of the autoimmune diseases is perhaps one of the examples to open the dead lock, since it may provide a direction for future therapeutic bimodal. It should also be kept in mind that previously described works in elucidating the mechanisms of autoimmune response were mainly carried out in the animal models, 
extrapolation of these findings in humans remains speculative and needs to be investigated further.

\section{REFERENCES}

1. Sinha AA, Lopez MT, McDevitt HO. Autoimmune diseases: the failure of self tolerance. Science 1990;248:1380-8.

2. Ramsdell F, Fowlkes BJ. Clonal deletion versus clonal anergy: the role of the thymus in inducing self tolerance. Science 1990;248:1342-8.

3. Blackman M, Kappler J, Marrack P. The role of the T cell receptor in positive and negative selection of developing $\mathrm{T}$ cells. Science 1990;248:1334-40.

4. Palmer DB, Hayday A, Owen MJ. Is TCR $B$ expression an essential event in early thymocyte development. Immunol Today 1993;14:460-2.

5. Anderson G, Jenkinson EJ, Moore NC, Owen JJT. MHC class II-positive epithelium and mesenchyme cells are both required for T-cell development in the thymus. Nature 1993;362:70-3.

6. Ardavin C, Wu L, Li C-L, Shortman K. Thymic dendritic cells and $\mathrm{T}$ cells develop simultaneously in the thymus from a common precursor population. Nature 1993;362:761-3.

7. MacDonald HR. Deletion versus anergy: the superantigen paradigm. Res Immunol 1992;143:307-10.

8. Baccalà R, Gonzàles-Quintial R, Theofilopoulos AN. Lack of evidence for central T-cell tolerance defects in lupus mice and for Vß-deleting endogenous superantigens in rats and humans. Res Immunol 1992;143:288-90.

9. Wilson DB, Steinman L, Gold DP. The V-region disease hypothesis: new evidence suggests it is probably wrong. Immunol Today 1993;14:376-80.

10. Hewitt CRA, Lamb JR. Peptide-mediated anergy in human $\mathrm{CD}^{+} \mathrm{T}$ cells. Res Immunol 1992;143:294-6.

11. Jenkins MK. The role of cell division in the induction of clonal anergy. Immunol Today 1992;13:69-73.

12. Miller JFAP, Morahan G. Peripheral T cell tolerance. Annu Rev Immunol 1992;10:51-69.

13. Lo D. Tolerance to peripheral antigens must involve nondeletional mechanisms. Res Immunol 1992;143:296-303.

14. Merino R, Iwamoto M, Fossati L, Muniesa P, Araki K, Takahashi S, et al. Prevention of systemic lupus erythematosus in autoimmune BXSB mice by transgene encoding I-E $\alpha$ chain. J Exp Med 1993;178:1189-97.

15. Arnold B, Schönrich G, Hämmerling GJ. Multiple levels of peripheral tolerance. Immunol Today 1993;14:12-4.

16. Protti MP, Manfredi AA, Horton RM, Bellone M, ContiTronconi BM. Myasthenia gravis:recognition of a human autoantigen at the molecular level. Immunol Today 1993;14:363-8.

17. Ofosu-Appiah W, Mokhtarian F, Shirazian D, Grob D. Production of anti-acetyl choline receptor-alpla antibody in vitro by peripheral blood lymphocytes of patients with myasthenia gravis: role of immunoregulatory $T$ cells and monocytes. J Lab Clin Med 1994;124:231-41.

18. Wucherpfennig KW, Weiner HL, Hafler DA. T-cell recognition of myelin basic protein. Immunol Today 1991;12:27782.
19. Toh BH, Gleeson PA, Van Driel IR. Autoimmunity: the paradigm of autoimmune gastritis. Today's Life Sci 1993;5(2):18-27.

20. Nossal GJV. Negative selection of lymphocytes. Cell 1994;76:229- 39.

21. Heath WR, Allison J, Hoffman MW, Schönrich G, Hämmerling $\mathrm{G}$, Arnold $\mathrm{B}$, et al. Autoimmune diabetes as a consecuence of locally produced IL-2. Nature 1992;359:547-9.

22. Heath WR, Miller JFAP. Expression of two $\alpha$ chains on the surface of $T$ cells in TCR transgenic mice. J Exp Med 1993;178:1807-11.

23. Mamula MJ. The inability to process a self-peptide allows autoreactive $\mathrm{T}$ cells to escape tolerance. J Exp Med 1993;177:567- 71.

24. Goodnow CC, Adelstein S, Basten A. The need for central and peripheral tolerance in the $B$ cell repertoire. Science 1990;248:1372-9.

25. Nemazee D. Mechanisms and meaning of B-lymphocyte tolerance. Res Immunol 1992;143:272-5.

26. Eibel H, Brombacher F, Köhler G. Analysis of B-cell tolerance in mice expressing transgenic anti-CD8.2 immunoglobulin M molecules. Res Immunol 1992;143:276-8.

27. Naparstek Y, Plotz PH. The role of autoantibodies in autoimmune disease. Annu Rev Immunol 1993;11:79-104.

28. Goodnow CC, Brink R, Adam E. Breakdown of selftolerance in anergy B lymphocytes. Nature 1991;352:532-6.

29. Sosroseno W, Herminajeng E. Interleukin 6 (IL-6): the biochemistry and its role in $\mathrm{B}$ and $\mathrm{T}$ cell development. Med J Univ Indon 1994;3:78-84.

30. Linker-Israeli M. Cytokine abnormalities in human lupus. Clin Immunol Immunopathol 1992;63:10-2.

31. Goldman M, Druet $P$, Gleichmann $E$. $T_{H} 2$ cells in systemic autoimmunity: insights from allogeneic diseases and chemically-induced autoimmunity. Immunol Today 1991;12: 223-7.

32. Waldman H. Manipulation of T-cell responses with monoclonal antibodies. Annu Rev Immunol 1989;7:407-44.

33. French DL, Laskov R, Scharff MD. The role of somatic hypermutation in the generation of antibody diversity. Science 1989;244:1152-7.

34. Shlomchik M, Mascelli M, Shan H, Radic MZ, Pisetsky D, Marshak-Rothstein A, Weigert M. Anti-DNA antibodies from autoimmune mice arise by clonal expansion and somatic mutation. J Exp Med 1990;171:265-97.

35. Singh AK. Abnormalities in the regulation of variable region genes that encode for antibodies to DNA may be a central factor in the pathogenesis of systemic lupus erythematosus. Ann Rheum Dis 1993;52:378-83.

36. Bloom BR, Salgame P, Diamond B. Revisting and revising suppressor T cells. Immunol Today 1992;13:131-5.

37. Kemeny DM, Noble A, Holmes BJ, Diaz-Sanchez D. Inmune regulation: a new role for the $\mathrm{CD} 8^{+} \mathrm{T}$ cells. Immunol Today 1994;15:107-10.

38. Meyers CM, Kelly CJ. Effector mechanisms in organspecific autoimmunity. I. Characterization of a $\mathrm{CD} 8^{+} \mathrm{T}$ cell line that mediates murine interstitial nephritis. J Clin Invest 1991;88:408-16. 
39. Neilson EG, McCafferty E, Mann R, Michaud L, Clayman $\mathrm{MD}$. Tubular antigen-derivatized cells induce a diseaseprotective, antigen-specific, and idiotype-specific suppressor $\mathrm{T}$ cell network restricted by I-J nad IgH-V in mice with experimental interstitial nephritis. J Exp Med 1985;162:21530.

40. Meyers CM, Kelly CJ. Inhibition of murine nephritogenic effector $\mathrm{T}$ cells by a clone-specific suppressor factor. $\mathrm{J}$ Clin Invest 1994;94:2093-104.

41. Tomer $Y$, Shoenfeld $Y$. The significance of $T$ suppressor cells in the development of autoimınunity. $J$ Autoimmun 1989;2:739-58.

42. Arnon R, Teitelbaum D. On the existence of suppressor cells. Int Arch Allergy Immunol 1993;100:2-7.

43. Miller A, Lider O, Roberts AB, Sporn MB, Weiner HL. Suppressor $\mathrm{T}$ cells generated by oral tolerization to myelin basic protein suppress both in vitro and in vivo immune responses by the release of transforming growth factor $B$ after anti gen-specific triggering. Proc Natl Acad Sci 1992;89: 421-5.

44. Varriale S, Béraud E, Barbaria J, Galibert R, Bernard D. Regulation of experimental autoimmune encephalomyelitis: Inhibition of adoptive experimental autoimmune encephalomyelitis by 'recovery-associated suppressor cells'. J Neuroimmunol 1994;53:123-31.

45. Mathieson PW, Stapleton KJ, Oliviera DBG, Lockwood CM. Immunoregulation of mercuric chloride-induced autoimmunity in Brown Norway rats: a role for $\mathrm{CD} 8^{+} \mathrm{T}$ cells revealed by in vivo depletion studies. Eur $\mathrm{J}$ Immunol 1991;21:2105-9.

46. Sosroseno W. The mechanisms of oral tolerance and immunotherapy. J Royal Soc Med 1995; (In press).

47. Weiner HL, Friedman A, Miller A, Khoury SJ, Al-Sabbagh A, Santos L, et al. Oral tolerance: Immunologic mechanisms and treatment of animal and human organ-specific autoimmune disease by oral administration of autoantigens. Annu Rev Immunol 1994;12:809-37.

48. Calder VL, Zhao ZS, Wang Y, Barton K, Lightman SL. Effects of CD8 depletion on retinal soluble antigen induced experimental autoimmune uveoretinitis. Immunology 1993;79:255-62.

49. Nussenblatt RB. Experimental autoimmune uveitis: Mechanisms of disease and clinical therapeutic indications. Invest Opthalmol Vis Sci 1991;32:3131-41.

50. Cohen JJ. A poptosis. Immunol Today 1993;14:126-30.

51. Kabelitz D, Polıl T, Pechhold K. Activation-induced cell death (apoptosis) of mature peripheral T lymphocytes. Immunol Today 1993;14:338-9.

52. Cohen PL, Eisenberg RA. The $l p r$ and $g / d$ in systermic autoinmunity: life and death in the Fas lane. Immunol Today 1992;13:427-8.

53. Wu J, Zhou T, He J, Mountz JD. Autoimmune disease in mice due to integration of an endogenous retrovirus in an apoptosis gene. J Exp Med 1993;178:461-8.

54. Chu JL, Drappa J, Parmassa A, Elkon KB. The defect of Fas mRNA expression in MRL-lpr mice is associated with insertion of the retrotransposon, ETn. J Exp Med 1993;178:72330.
55. Cheng J, Zhou T, Liu C, Shapiro JP, Brauer MJ, Kiefer MC, et al. Identification of a soluble form of the fas molecule that protect cells from fas-mediated apoptosis. Science 1994; 263;1759-61.

56. Korsmeyer SJ. Bcl-2: a repressor of lymphocyte death. Immunol Today 1992;13:385-6.

57. Núñez G, Merino R, Grillot D, González-Garcia M. Bcl-2 and Bcl-x:regulatory switches for lymphoid death and survival. Immunol Today 1994;582-8.

58. Strasser A, Whittingham S, Vaux DI, Bath ML, Adams JM, Cory S, Harris AW. Enforced BCL2 expression in B-lymphoid cells prolongs antibody responses and elicits autoimmune disease. Proc Natl Acad Sci USA 1991;88:8661-5.

59. Aringer M, Wintersberger W, Steiner $C W$, Kiener H, Presterl $\mathrm{E}$, Jaeger $\mathrm{U}$, et al. High levels of $\mathrm{Bcl}-2$ protein in circulating T lymplocytes, but not B lymphocytes, of patients with systemic lupus erythematosus. Arthr Rheum 1994;37:142330.

60. Naumovski L, Cleary ML. Bcl2 inhibits apoptosis associated with terminal differentiation of HL-60 myeloid leukemia cells. Blood 1994;83:2261-7.

61. Bach JP. Insulin-dependent diabetes mellitus as an autoimmune disease. Endocrine Rev 1994;15:516-42.

62. Marrack P, Kappler J. The staphylococcal enterotoxins and their relatives. Science 1990;248:705-11.

63. Taylor JE, Ross DA, Goodacre JA. Group A streptococcal antigens and superantigens in the pathogenesis of autoimmune arthritis. Eur J Clin Invest 1994;24:511-21.

64. Held W, Acha-Orbea H, MacDonald HR, Waanders GA. Superantigens and retroviral infection: insights from mouse mammary tumor virus. Immunol Today 1994;15:184-90.

65. Acha-Orbea H. Bacterial and viral superantigens: roles on autoimmunity. Ann Rheum Dis 1993;52:S6-S16.

66. Christensen T, Mфller-Larsen A, Haahr S. A retroviral implication in multiple sclerosis? TIM 1994;2:332-6.

67. Renno T, Zeine R, Girard JM, Gillani S, Dodelet V, Owens $T$. Selective enrichment of $T_{h} 1$ CD45RB ${ }^{\text {low }} \mathrm{CD}^{+} \mathrm{T}$ cells in autoimmune infiltrates in experimental allergic encephalomyelitis. Int Immunol 1994;6:347-54.

68. Nagelkerken L, Gollob KJ, Tielemans M, Coffinan RL. Role of transforming growth factor- $\beta$ in the preferential induction of $T$ helper cells of type 1 by staphylococcal enterotoxin B. Eur J Immunol 1993;23:2306-10.

69. Schmitz J, Assenmacher M, Radbruch A. Regulation of T helper cell cytokine expression: functional dichotomy of antigen-presenting cells. Eur J Immunol 1993;23:191-9.

70. Gollob KJ, Nagelkerken L, Coffman RL. Endogenous retroviral superantigen presentation by $B$ cells induces the development of type $1 \mathrm{CD}^{+} \mathrm{T}$ helper lymphocytes. Eur J Iminunol 1993;23:2565-71.

71. Zagon G, Tumang JR, Li Y, Friedman SM, Grow MK. Increased frequency of VB17-positive T cells in patients with rheumatoid arthritis. Arthr Rheum 1994;37:1431-40.

72. Mountz JD, Zhout T, Long RE, Bluethmann H, Koopman WJ, Edward CK III. T cell influence on superantigen-induced arthritis in MRL-lpr/lpr mice. Arthr Rheum 1994;37:113-24.

73. Brocke S, Veroma T, Weissman IL, Gijbels K, Steiman L. Infection and multiple sclerosis: a possible role for superantigens? TIM 1994;2:250-4. 
74. Kim J, Urban RG, Strominger JL, Wiley DC. Toxic shock syndrome toxin-1 complexed with a class II major histocompatibility molecule HLA-DR1. Science 1994;266;1870-4.

75. Thbodeau J, Cloutier I, Lavoie PM, Labrecque N. Mourad W, Jardetzky T, et al. Subset of HLA-DR1 molecules defined by SEB and TSST-1 binding. Science 1994;216:1874-8.

76. Woodland DL, Blackman MA. How do T-cell receptors, MHC molecules and superantigens get together? Immunol Today 1993;14:208-12.

77. Brennan FM, Feldman M. Cytokines in autoimmunity. Curr Opin Immunol 1992;4:754-9.

78. Opdenakker G, Van Damme J. Cytokine-regulated proteases in autoimmune diseases. Inmunol Today 1994;15:103-6.

79. Sosroseno W, Herminajeng $\mathrm{E}$. The immunoregulatory role of transforming gowth factor beta (TGF- $\beta$ ): a review. $\mathrm{Br} \mathrm{J}$ Biomed Sci 1995; (In press).

80. Wall SM, Allen JB, Costa GL, Wong HL, Dasch JR. Reversal of acute and chronic synovial inflammation by anti-transforming growth factor B. J Exp Med 1993;177:225-30.

81. Herton LR, Coffman RL, Bond MW, Kotzin BL. Increased autoantibody production by NZB/NZW B cells in response to IL-5. J Immunol 1988;141:842-8.

82. Ishida $H$, Muchamuel T, Sakaguchi S, Adrade S, Menon S, Howard M. Continuous administration of anti-interleukin 10 antibodies delays onset of autoimmunity in NZB/W $F_{1}$ mice. J Exp Med 1994;179:305-10.

83. Hamzaoui K, Ayed K, Slim A, Hamza M, Touraine J. Natural killer cell activity, interferon-gamma and antibodies to herpes viruses in patients with Behçet's disease. Clin Exp Immunol 1990;79:28-34.

84. Kaneko F, Minagawa T, Takiguchi Y, Suzuki M, Itoh N. Role of cell-mediated immune reaction in blister formation of bullous pemphigoid. Dermatology 1992;184:34-9.

85. Sugita $Y$, Nagatani T, ikezawa Z, Nomura K, Watanabe $Y$, Uitto J, Nakajima H. Modulation of bullous pemphigoid antigen gene expression by $\gamma$-interferon in cultured keratinocytes. Br J Dermatol 1992;126:468-73.

86. Akahoshi T, Wada C, Eno H, Hirota K, Hosaka S, Takagishi, et al. Expression of monocyte chemotatic and activating factor in rheumatoid arthritis. Arthr Rheum 1993;36:762-71.
87. Hulkower KI, Wertheimer SJ, Levin W, Coffey JW, Anderson $\mathrm{CM}$, Chen $\mathrm{T}$, et al. Interleukin-1B induces cytosolic phospholipase $\mathrm{A}_{2}$ and prostaglandin $\mathrm{H}$ synthase in rheumatoid synovial fibroblasts. Arthr Rheum 1994;37:65361.

88. Thomas R, Carroll GJ. Reduction of leukocyte and interleukin-1B concentration in the synovial fluid of rheumatoid arthritis patients treated with methotrexate. Arthr Rheum 1993;36:1244-52.

89. Manicourt DH, Triki R, Fukuda K, Devogelaer JP, de Deuxchaisnes CN, Thonar EJMA. Levels of circulating tumor necrosis factor $\alpha$ and interleukin- 6 in patients with rheumatoid arthritis. Arthr Rheum 1993;36:490-9.

90. William RO, Feldmann M, Maini RN. Anti-TNF ameliorates joint disease in murine collagen-induced arthritis. Proc Natl Acad Sci USA 1992;89:9784-8.

91. Greczy AF, Edwards CM, McGuigan LE, Sullivan JS. Cross-reacting determinants in ankylosing spondylitis. ISI Atlas Sci Immunol 1988;1:7-10.

92. Baum H, Butler P, Davies H, Sternberg MJE, Burroughs AK. Autoimmune disease and molecular mimicry: an hypothesis. TIBS 1993;18:140-4.

93. Wordsworth P. Rheumatoid arthritis. Curr Opin Immunol 1992;4:766- 9 .

94. Rook GAW, Lydyard PM, Stanford JL. A reappraisal of the evidence that rheumatoid arthritis and several other jdiopathic diseases are slow bacterial infections. Ann Rheum Dis 1993;52:S30-8.

95. McCulloch J, Lydyard PM, Rook GAW. Rheumatoid arthritis: how well do the theories fit the evidence? Clin Exp Immunol 1993;92:1-6.

96. Lehner T, Lavery E, Smith R, van der Zee R, Mizushima Y, Shinnick T. Association between the 65-kilodalton heat shock protein, Streprococcus sanguis, and the corresponding antibodies in Behçet's syndrome. Infect Immun 1991;59:1434-41.

97. Stanford MR, Kasp E, Whiston R, Hasan A, Todryk S, Shinnick $T$, et al. Heat shock protein peptides reactive in patients with Behcet's disease are uveitogenic in Lewis rats. Clin Exp Inmunol 1994;97:226-31. 